\title{
Comparison of fucosterol content in algae using high-performance liquid chromatography
}

\author{
Jeong Min Lee ${ }^{\dagger}$, Jae Hyuk Jeon ${ }^{\dagger}$, Mi-Jin Yim, Grace Choi, Myeong Seok Lee, Yun Gyeong Park and Dae-Sung Lee
}

\begin{abstract}
Background: Fucosterol is a compound commonly found in algae that has various biological activities. The purpose of this study was to develop a high-performance liquid chromatography (HPLC) validation method for fucosterol and to compare the fucosterol contents of 11 algal species from Ulleungdo, Korea.

Method: In this study, we successfully isolated and identified fucosterol from a 70\% EtOH extract of Sargassum miyabei, and subsequently conducted specificity, linearity, limit of detection (LOD), limit of quantification (LOQ), accuracy, and precision analyses for development of an HPLC validation method. Fucosterol contents were compared using the established HPLC validation conditions.

Results: We successfully isolated fucosterol from a 70\% EtOH extract of S. miyabei and identified it based on spectroscopic analysis. On the basis of HPLC validation using the fucosterol isolated from S. miyabei, we confirmed specificity (8.5 min), linearity $\left(R^{2}=0.9998\right), \operatorname{LOD}\left(3.20 \mu \mathrm{g} \mathrm{mL}{ }^{-1}\right)$, LOQ $\left(9.77 \mu \mathrm{g} \mathrm{mL}^{-1}\right)$, accuracy (intra-day and inter-day variation, 90-110\%), and precision (RSD, 1.07\%). Fucosterol contents in the 11 assessed algal species ranged from 0.22 to $81.67 \mathrm{mg} \mathrm{g}^{-1}$, with the highest content being recorded in a $70 \% \mathrm{EtOH}$ extract of Desmarestia tabacoides $\left(81.67 \mathrm{mg} \mathrm{g}^{-1}\right)$, followed by that of Agarum clathratum $\left(78.70 \mathrm{mg} \mathrm{g}^{-1}\right)$.

Conclusions: The results indicate that $70 \% \mathrm{EtOH}$ extracts of $\mathrm{D}$. tabacoides and A. clathratum containing fucosterol with various effects can be potential alternative sources of fucosterol.
\end{abstract}

Keywords: Alga, Fucosterol, High-performance liquid chromatography, Validation

\section{Background}

Algae are classified into three main classes, namely, Chlorophyceae, Phaeophyceae, and Rhodophyceae, and there are approximately 6000 algal species worldwide, of which approximately 150 species are used as food (Devi et al. 2011; Meenakshi et al. 2011). Algae are known to be a rich source of bioactive substances such as carotenoids, dietary fiber, proteins, minerals, vitamins, polyphenols, and low-calorie polyunsaturated fatty acids. Research and development of health foods, cosmetics, and medicines using algae have been

\footnotetext{
* Correspondence: daesung@mabik.re.kr

†Jeong Min Lee and Jae Hyuk Jeon contributed equally to this work. Department of Genetic Resources Research, National Marine Biodiversity Institute of Korea, Seocheon, Republic of Korea
}

increasing globally (Lee et al. 2011). As aquatic algae can inhabit extreme environments, unlike terrestrial organisms, they are known to produce various bioactive substances that enable them to adapt to such environments (Jeon et al. 2012). Owing to the presence of these bioactive substances, algae have been reported to possess anticancer, antioxidant, antibacterial, antitrypanosomal, antiangiogenic, and anti-HIV activities (Synytsya et al. 2010; Veiga-Santos et al. 2010; Souza et al. 2012; Guerra Dore et al. 2013; Shanmugam et al. 2014; Thuy et al. 2015).

Several bioactive substances, including fucoidan (polysaccharide), fucoxanthin, chlorophyll, xanthophyll (carotenoid), phlorotannin (tannin), and fucosterol (sterol) have been isolated from algae (Hosokawa et al. 2004). Fucosterol is

(c) The Author(s). 2020 Open Access This article is licensed under a Creative Commons Attribution 4.0 International License, which permits use, sharing, adaptation, distribution and reproduction in any medium or format, as long as you give appropriate credit to the original author(s) and the source, provide a link to the Creative Commons licence, and indicate if changes were made. The images or other third party material in this article are included in the article's Creative Commons licence, unless indicated otherwise in a credit line to the material. If material is not included in the article's Creative Commons licence and your intended use is not permitted by statutory regulation or exceeds the permitted use, you will need to obtain permission directly from the copyright holder. To view a copy of this licence, visit http://creativecommons.org/licenses/by/4.0/. 
commonly found in algae and has been reported to lower cholesterol levels and possess various physiological activities, such as antidiabetic, anticancer, and antioxidant activities (Ikeda et al. 1988; Tang et al. 2002; Lee et al. 2004; Ham et al. 2010).

Currently, fucosterol is mainly isolated from Sargassum species. In this study, we isolated fucosterol from Sargassum miyabei and developed a highperformance liquid chromatography (HPLC) validation method for this compound. Furthermore, we compared the content of fucosterol in 11 algal species from Ulleungdo, Korea, using the established HPLC validation conditions.

\section{Methods}

\section{Samples of algae}

In 2015, eleven species of algae (Agarum clathratum, Caulerpa okamurae, Codium fragile, Desmarestia tabacoides, Dictyopteris divaricata, Ecklonia cava, Eisenia bicyclis, Myagropsis myagroides, Sargassum horneri, S. serratifolium, and Sporochnus radiciformis) were collected in Ulleungdo Island, Korea, for comparison of fucosterol contents. In the same year, S. miyabei was collected in Pohang-si, Korea, for isolation of fucosterol. The specimens have been deposited in the Marine Biodiversity Institute of Korea (MABIK). All algal samples were lyophilized, pulverized, and extracted with 70\% EtOH using a sonicator (WUC-N30H; DAIHAN Scientific Co., Ltd., Wonju, Korea).

\section{Instrument and reagents}

Medium-pressure liquid chromatography (MPLC) and HPLC were performed using the Buchi Sepacore Flash system (Flawil, Switzerland) consisting of a UV photometer C-640 and Agilent 1260 Infinity system (Tokyo, Japan) equipped with a diode array detector (DAD). Mass spectrometry (MS) was conducted using a JEOL JMS-600-W Spectrometer (Tokyo, Japan), and nuclear magnetic resonance (NMR) spectra were recorded using a Bruker AVANCE 500 NMR spectrometer (Rheinstetten, Germany) in $\mathrm{CDCl}_{3}$ with tetramethylsilane used as the internal standard. Chemical shifts are reported in parts per million $(\delta)$ and the coupling constant $(J)$ is expressed in Hertz $(\mathrm{Hz})$. All reagents used were of analytical grade.

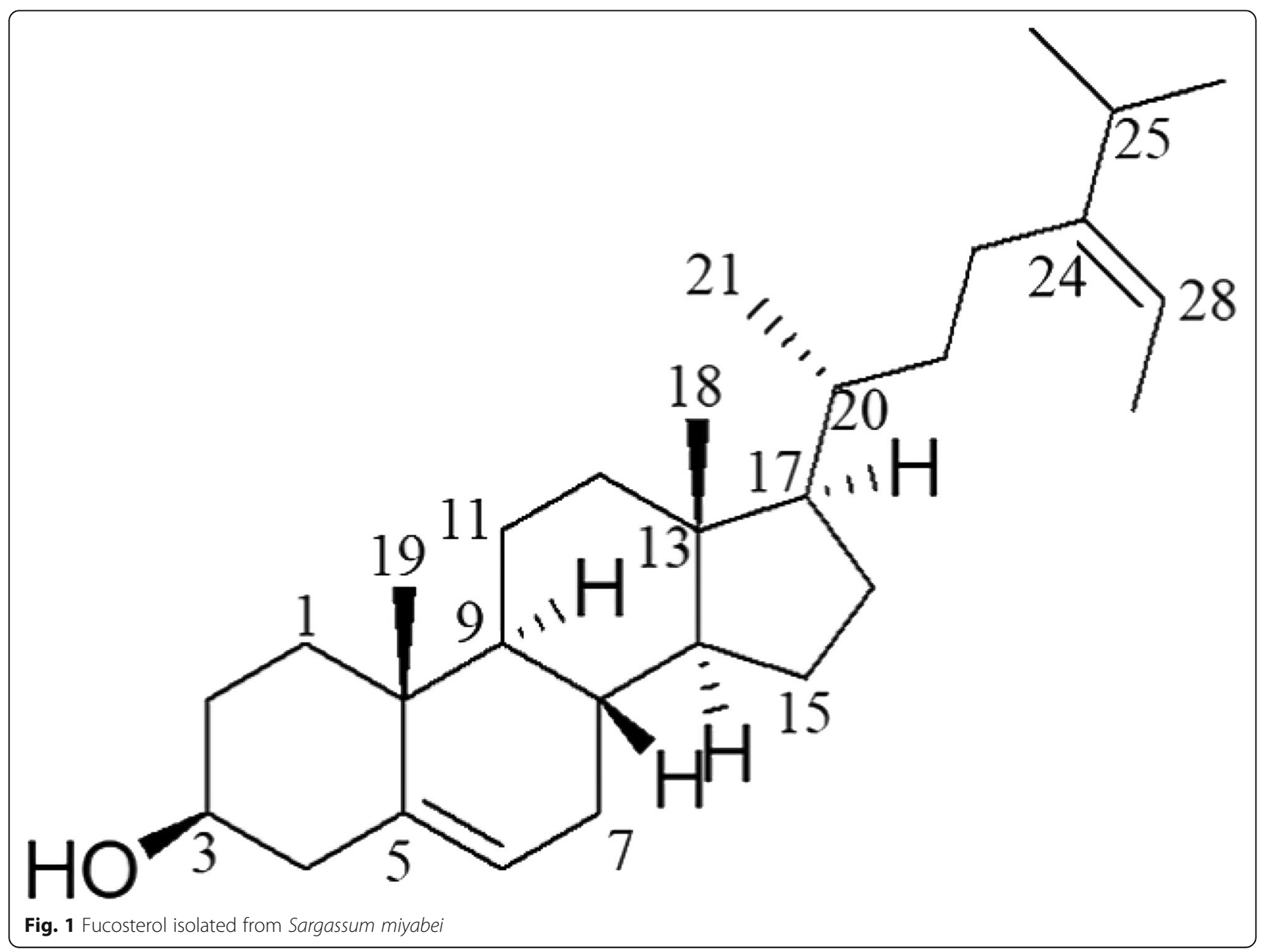




\section{Isolation of fucosterol}

A dried sample of $S$. miyabei $(1.2 \mathrm{~kg})$ was powdered and extracted with $70 \% \mathrm{EtOH}(12 \mathrm{~L} \times 3)$ using a sonicator and then evaporated under vacuum. The $70 \% \mathrm{EtOH}$ extract $(91.7 \mathrm{~g})$ was suspended in water and partitioned with $n$-hexane, chloroform, ethyl acetate, and $n$-butanol. A portion of the $n$-hexane fraction $(15.6 \mathrm{~g})$ was subjected to chromatographic analysis using an MPLC system and eluted in a gradient solvent system (100\% $n$-hexane and up to $100 \%$ ethyl acetate) to yield eight subfractions (H1-H8). Subfraction H5 (8.1 g, n-hexane:ethyl acetate $=60: 40)$ was re-chromatographed in an MPLC system and eluted in a gradient solvent system $(70 \%$ $n$-hexane and up to $100 \%$ ethyl acetate) to yield five subfractions (H5-1 to H5-5). H5-3 was recrystallized with $\mathrm{MeOH}$ to obtain fucosterol (Fig. 1).

Fucosterol was obtained as a white powder; EI-MS $\mathrm{m} /$ $z: 412[\mathrm{M}]^{+}$(13.0), 314 (100), 299 (19.2), 271 (11.3), 229 (15.5); ${ }^{1} \mathrm{H}-\mathrm{NMR}\left(500 \mathrm{MHz}, \mathrm{CDCl}_{3}, \delta_{\mathrm{H}}\right) 5.35(1 \mathrm{H}, \mathrm{d}, J=$ $5.5 \mathrm{~Hz}, \mathrm{H}-6), 5.18(1 \mathrm{H}, \mathrm{q}, J=6.5,13.5 \mathrm{~Hz}, \mathrm{H}-28), 3.53$ $(1 \mathrm{H}, \mathrm{m}, \mathrm{H}-3), 1.58(3 \mathrm{H}, \mathrm{d}, J=7.5 \mathrm{~Hz}, \mathrm{H}-29), 1.02(3 \mathrm{H}, \mathrm{s}$, $\mathrm{H}-19), 1.00(3 \mathrm{H}, \mathrm{d}, J=7.0 \mathrm{~Hz}, \mathrm{H}-21), 0.98(3 \mathrm{H}, \mathrm{d}, J=$ $6.5 \mathrm{~Hz}, \mathrm{H}-27), 0.97(3 \mathrm{H}, \mathrm{d}, J=7.0 \mathrm{~Hz}, \mathrm{H}-26), 0.69(3 \mathrm{H}, \mathrm{s}$, $\mathrm{H}-18) ;{ }^{13} \mathrm{C}-\mathrm{NMR}\left(125 \mathrm{MHz}, \mathrm{CDCl}_{3}, \delta_{\mathrm{C}}\right) 147.2$ (C-24), 141.0 (C-5), 121.9 (C-6), 115.8 (C-28), 72.0 (C-3), 56.9 (C-14), 56.0 (C-17), 50.3 (C-9), 42.5 (C-13), 42.4 (C-4), 39.9 (C-12), 37.5 (C-1), 36.7 (C-10), 36.6 (C-20), 35.4 (C-22), 35.0 (C-25), 32.1 (C-7,8), 31.9 (C-2), 28.4 (C16), 25.9 (C-23), 24.5 (C-15), 22.4 (C-26), 22.3 (C-27), 21.3 (C-11), 19.6 (C-19), 19.0 (C-21), 13.4 (C-29), $12.1(\mathrm{C}-18)$.

\section{Sample preparation and HPLC condition}

A stock solution of fucosterol (1 mg) was dissolved in $1 \mathrm{~mL}$ of acetonitrile and was diluted to give the desired concentrations (3.91, 7.82, 15.63, 31.25, 62.50 , and $125.00 \mu \mathrm{g} \mathrm{mL} \mathrm{m}^{-1}$ ). To analyze fucosterol content, samples of the 11 aforementioned algal species were extracted with $70 \% \mathrm{EtOH}$ for $1 \mathrm{~h}$ by sonication (three times) and evaporated under vacuum. The residues were dissolved in $1 \mathrm{~mL}$ of $50 \%$ $\mathrm{MeOH}$ and filtered using a $0.45-\mu \mathrm{m}$ syringe filter. The resulting solution was subjected to HPLC analysis, using a Kinetex C18 $(4.6 \mathrm{~mm} \times 100 \mathrm{~mm}$, $2.6 \mu \mathrm{m})$ column, with a mobile phase comprising a solution of $\mathrm{MeOH}$ (solvent $\mathrm{A}$ ) and $0.1 \%$ acetic acid (solvent B). The gradient solvent system was as follows: from 50 to $0 \% \mathrm{~B}$ for $5 \mathrm{~min}$, and then retained at $0 \% \mathrm{~B}$ for $10 \mathrm{~min}$. The injection volume was $10 \mu \mathrm{L}$ and the flow rate was $1 \mathrm{~mL} \mathrm{~min}^{-1}$. The column temperature was maintained at $25^{\circ} \mathrm{C}$ and detection wavelength was $210 \mathrm{~nm}$. All injections were performed in triplicate.

\section{Validation}

The HPLC method was validated for specificity, linearity, limit of detection (LOD), limit of quantification (LOQ), accuracy, and precision according to the International Conference on Harmonization (ICH; 1997, 2005) guidelines.

The linearity of the method was established using triplicate injections at six concentrations in the range $3.91-125.00 \mu \mathrm{g} \mathrm{mL} \mathrm{m}^{-1}$. A calibration curve for fucosterol was constructed using peak area $(Y)$, concentration $\left(X, \mu \mathrm{g} 10 \mu \mathrm{L}^{-1}\right)$, and mean $(n=3) \pm$ standard deviation values. Correlation coefficient values $\left(R^{2}\right)$ were determined from the calibration curve. The LOD and LOQ of fucosterol were calculated using the following formulae: $\mathrm{LOD}=3.3 \times \sigma /$ $S$ and LOQ $=10 \times \sigma / S$; where, $\sigma=$ the deviation and $S=$ the slope of the calibration curve. The accuracy of the method was determined based on intra- and inter-day variations. Intra-day variation was determined by analyzing triplicate samples at three different concentrations (15.63, 31.25, $62.50 \mu \mathrm{g} \mathrm{mL}^{-1}$ ) in a single day. Inter-day variation was determined by analyzing a single sample at three different concentrations (15.63-62.50 $\mu \mathrm{g}$ $\mathrm{mL}^{-1}$ ) for 3 days. Variations are expressed as percentage recoveries. Precision was assessed based on repeatability. Repeatability data were obtained from six injections of samples at a concentration of $125.00 \mu \mathrm{g} \mathrm{mL}^{-1}$ on the same day. Repeatability is expressed as the percentage relative standard deviation (\%RSD).

\section{Results and discussion} Isolation of fucosterol

The fucosterol extracted from S. miyabei was obtained as a white powder with a molecular formula of $\mathrm{C}_{29} \mathrm{H}_{48} \mathrm{O}$ based on EI-MS analysis. In the ${ }^{1} \mathrm{H}-\mathrm{NMR}$ spectrum of fucosterol, we detected two olefinic proton signals $\left[\delta_{\mathrm{H}} 5.35(1 \mathrm{H}, \mathrm{d}, J=5.5 \mathrm{~Hz}, \mathrm{H}-6), 5.18\right.$ $(1 \mathrm{H}, \mathrm{q}, J=6.5,13.5 \mathrm{~Hz}, \mathrm{H}-28)]$, one oxygenated methine proton signal $\left[\delta_{\mathrm{H}} 3.53(1 \mathrm{H}, \mathrm{m}, \mathrm{H}-3)\right]$, and six methyl groups $\left[\delta_{\mathrm{H}} 1.58(3 \mathrm{H}, \mathrm{d}, J=7.5 \mathrm{~Hz}, \mathrm{H}-29)\right.$, $1.02(3 \mathrm{H}, \mathrm{s}, \mathrm{H}-19), 1.00(3 \mathrm{H}, \mathrm{d}, J=7.0 \mathrm{~Hz}, \mathrm{H}-21)$, $0.98(3 \mathrm{H}, \mathrm{d}, J=6.5 \mathrm{~Hz}, \mathrm{H}-27), 0.97(3 \mathrm{H}, \mathrm{d}, J=7.0$ $\mathrm{Hz}, \mathrm{H}-26), 0.69$ (3H, s, $\mathrm{H}-18)]$. In the ${ }^{13} \mathrm{C}-\mathrm{NMR}$ spectrum of fucosterol, we observed 29 carbon signals, including two olefin quaternary carbons $\left[\delta_{C}\right.$ 147.2 (C-24), 141.0 (C-5)], two olefin methine carbons $\left[\begin{array}{lllll}\delta_{\mathrm{C}} & 121.9 & (\mathrm{C}-6), & 115.8 & (\mathrm{C}-28)\end{array}\right]$, one oxygenated methine carbon $\left[\delta_{\mathrm{C}} 72.0(\mathrm{C}-3)\right]$, and six methyl carbons $\left[\delta_{\mathrm{C}} 22.4(\mathrm{C}-26), 22.3\right.$ (C-27), 19.6 (C-19), 19.0 (C-21), 13.4 (C-29), 12.1 (C-18)]. Fucosterol was elucidated by comparison of the EI-MS and NMR $\left({ }^{1} \mathrm{H}\right.$-NMR, ${ }^{13} \mathrm{C}$-NMR, DEPT 45, 90, 135, ${ }^{1} \mathrm{H}_{-}{ }^{1} \mathrm{H}$ COSY, 


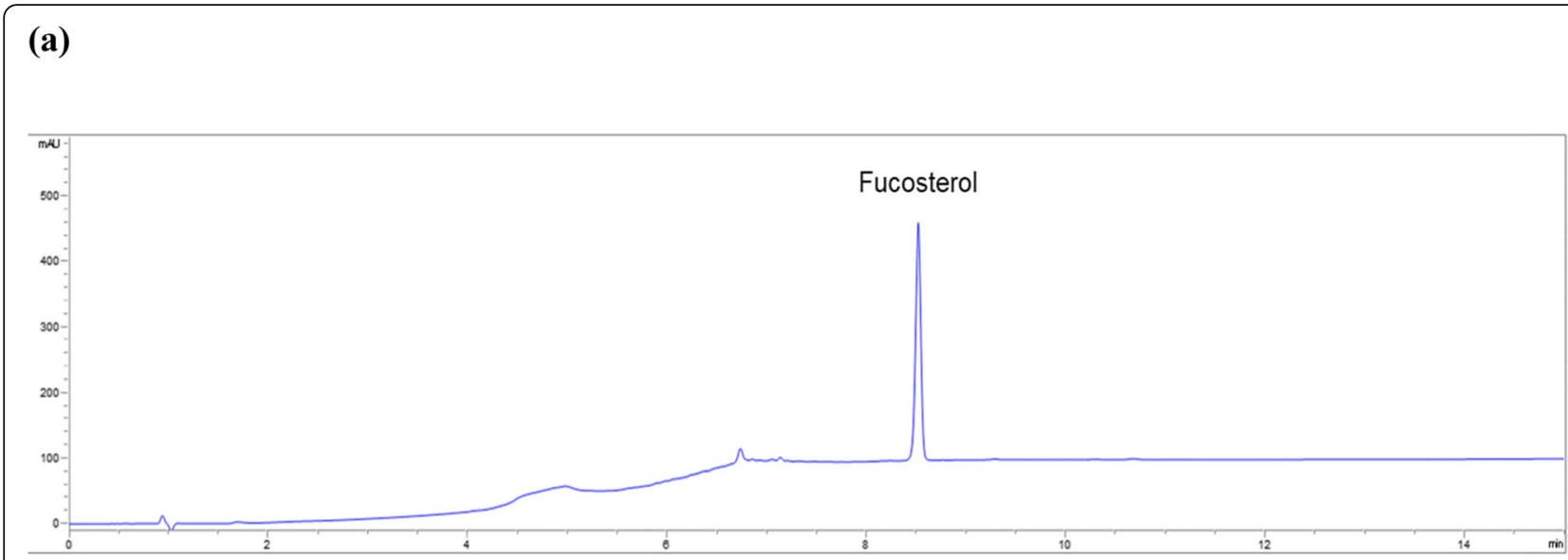

(b)

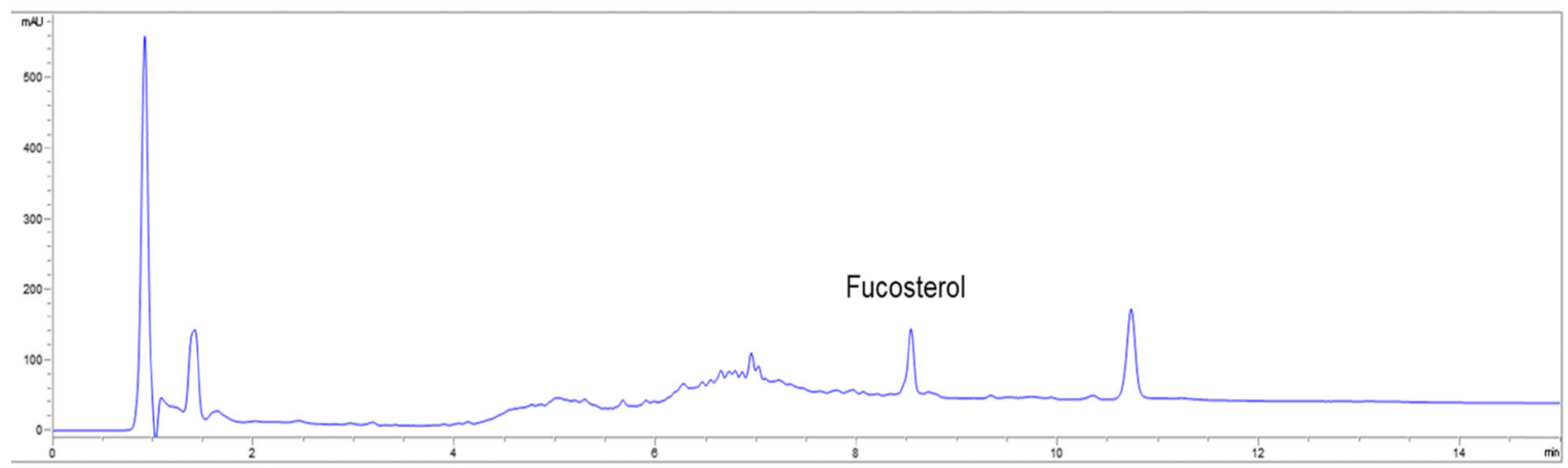

Fig. 2 High-performance liquid chromatography chromatograms of the fucosterol extracted from Agarum clathratum (a) and Desmarestia tabacoides (b)

HSQC, HMBC) spectral data with those previously published (Bang et al. 2011).

\section{Validation}

In the HPLC data, fucosterol showed a single peak unaffected by solvent and other components at 8.5 min (Fig. 2a). Good resolution of fucosterol and specificity of the method were confirmed. In the calibration curve at six different concentrations (3.91$125.00 \mu \mathrm{g} \mathrm{mL} \mathrm{m}^{-1}$ ) of fucosterol for determining linearity, $y$ was $5.70 x-23.90$ and $R^{2}$ was 0.9998 . The $R^{2}$ of

Table 1 High-performance liquid chromatography calibration data for fucosterol from S. miyabei

\begin{tabular}{lllll}
\hline $\begin{array}{l}\text { Linear range } \\
\left.(\mu \mathrm{g} \mathrm{mL})^{-1}\right)\end{array}$ & $\begin{array}{l}\text { Regression } \\
\text { equation }\end{array}$ & $\begin{array}{l}\text { Correlation } \\
\text { coefficient }\left(R^{2}\right)\end{array}$ & $\begin{array}{l}\mathrm{LOD} \\
\left.(\mu \mathrm{g} \mathrm{mL})^{-1}\right)^{b}\end{array}$ & $\begin{array}{l}\mathrm{LOQ} \\
\left.(\mu \mathrm{g} \mathrm{mL})^{-1}\right)^{c}\end{array}$ \\
\hline $3.91-125.00$ & $y=5.7 x+23.9$ & 0.9998 & 3.20 & 9.77 \\
\hline
\end{tabular}

Triplicate injections at six concentrations

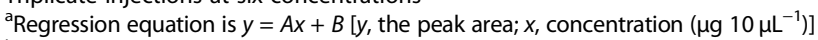

bLimit of detection

'Limit of quantification fucosterol was greater than 0.9995 , thereby verifying the linearity of fucosterol. The LOD and LOQ of fucosterol were 3.20 and $9.77 \mu \mathrm{g} \mathrm{mL} \mathrm{m}^{-1}$, respectively (Table 1). The intra- and inter-day accuracy ranges were $95.76-103.21 \%$ and $96.49-101.46 \%$, respectively. The intra- and inter-day variations were within the range of $90-110 \%$, which confirmed the accuracy of the method (Table 2). The precision of the HPLC

Table 2 Accuracy of the high-performance liquid chromatography validation method for fucosterol from $\mathrm{S}$. miyabei

\begin{tabular}{llllll}
\hline $\begin{array}{lllll}\text { Concentration } \\
\left(\mu \mathrm{g} \mathrm{mL}^{-1}\right)\end{array}$ & \multicolumn{2}{l}{ Intra-day variation $^{\mathrm{a}}$} & & \multicolumn{2}{l}{ Inter-day variation $^{\mathrm{b}}$} \\
\cline { 2 - 3 } 31.25 & Recovery (\%) & SD (\%) & & Recovery (\%) & SD (\%) \\
\hline 62.50 & 101.05 & 0.71 & & 101.46 & 0.59 \\
15.63 & 103.22 & 0.13 & & 99.55 & 0.28 \\
\hline
\end{tabular}

aTriplicate injections at three different concentrations in a single day ${ }^{\mathrm{b}}$ One injection at three different concentration for 3 days 
Table 3 Precision of the high-performance liquid chromatography validation method for fucosterol from S. miyabei

\begin{tabular}{lllll}
\hline $\begin{array}{l}\text { Concentration } \\
\left(\mu \mathrm{gL} \mathrm{m}^{-1}\right)\end{array}$ & $\begin{array}{l}\text { Number of } \\
\text { measurements }\end{array}$ & Area & Mean & RSD (\%) \\
\hline 125.00 & 1 & 682.8 & 685.4 & 1.05 \\
& 2 & 674.5 & & \\
& 3 & 681.7 & & \\
& 4 & 688.0 & & \\
& 5 & 692.0 & \\
& 6 & 693.6 & \\
\hline
\end{tabular}

method, calculated as \%RSD, was evaluated for repeatability $\left(125.00 \mu \mathrm{g} \mathrm{mL}^{-1}\right)$. The RSD was less than $2.0 \%(1.07 \%)$, which confirmed the precision of the method (Table 3).

\section{Determination of fucosterol contents}

The fucosterol contents in the 11 assessed algal species ranged from 0.22 to $81.67 \mathrm{mg} \mathrm{g}^{-1}$ (Table 4). Specifically, the content of fucosterol in A. clathratum, D. tabacoides, E. cava, and S. radiciformis was approximately four times higher than that in Sargassum species. The highest content of fucosterol was detected in the $70 \% \mathrm{EtOH}$ extract of $D$. tabacoides $\left(81.67 \mathrm{mg} \mathrm{g}^{-1}\right.$, Fig. $\left.2 \mathrm{~b}\right)$, followed by that of A. clathratum $\left(78.70 \mathrm{mg} \mathrm{g}^{-1}\right)$.

Fucosterol has been reported to have various effect such as antioxidant, antidepressant, anticonvulsant, antipredator, and antiplasmodial activities, and it has been isolated from the Sargassum species S. micracanthum, S. tenerrimum, $S$. fusiforme, S. horneri, and S. linearifolium (Ham et al. 2010;

Table 4 Content of fucosterol in $70 \% \mathrm{EtOH}$ extracts of 11 algal species

\begin{tabular}{ll}
\hline Sample & $\begin{array}{l}\text { Content of } \\
\text { fucosterol } \\
\left(\mathrm{mg} \mathrm{g}^{-1}\right)\end{array}$ \\
\hline Agarum clathratum & $78.70 \pm 0.01^{\mathrm{a}}$ \\
Caulerpa okamurae & $0.22 \pm 0.02$ \\
Codium fragile & $\mathrm{N} . \mathrm{D} .^{\mathrm{b}}$ \\
Desmarestia tabacoides & $81.67 \pm 0.07$ \\
Dictyopteris divaricata & Trace \\
Ecklonia cava & $48.03 \pm 0.14$ \\
Eisenia bicyclis & $13.10 \pm 0.07$ \\
Myagropsis myagroides & $3.13 \pm 0.01$ \\
Sargassum horneri & $2.63 \pm 0.02$ \\
Sargassum serratifolium & $19.75 \pm 0.04$ \\
Sporochnus radiciformis & $21.13 \pm 0.02$ \\
\hline
\end{tabular}

Data are expressed as the mean $\pm \mathrm{SD}(n=3)$ in $\mu \mathrm{g} \mathrm{\textrm {mL } ^ { - 1 }}$

${ }^{\mathrm{b}}$ Not detected
Terasaki et al. 2009; Zhen et al. 2015; Majik et al. 2015; Perumal et al. 2018). Although Sargassum species are a good source of fucosterol, our present study results confirmed that $70 \% \mathrm{EtOH}$ extracts of $D$. tabacoides and $A$. clathratum could replace Sargassum species as a potential source of fucosterol. Therefore, we anticipate that $D$. tabacoides and $A$. clathratum, which have high fucosterol contents with the various aforementioned properties, will have a high industrial value.

\section{Conclusions}

We successfully isolated fucosterol from S. miyabei and developed an HPLC validation method for this compound for comparison of the fucosterol contents of 11 selected algal species. The recorded fucosterol contents in $70 \% \mathrm{EtOH}$ extracts of $D$. tabacoides and A. clathratum were 81.67 and $78.70 \mathrm{mg} \mathrm{g}^{--1}$, respectively. These results indicate that $70 \%$ EtOH extracts of D. tabacoides and A. clathratum containing high contents of fucosterol with various beneficial properties can be potential alternative sources of fucosterol.

\section{Acknowledgements}

This work was supported by the National Marine Biodiversity Institute of Korea (2020M00500).

\section{Authors' contributions}

$J M L$ isolated the compounds, elucidated the structures, and wrote the manuscript. JHJ performed validations of the HPLC method and investigated the content of fucosterol in the algae. MJY and GC collected algal samples and assisted in the preparation of the manuscript. YGP and MSL contributed to plant material preparation. DSL designed and managed the research program. All authors read and approved the final manuscript.

\section{Funding}

This work was supported by the National Marine Biodiversity Institute of Korea (2020M00500).

Availability of data and materials

All data generated or analyzed during this study are included in this published article.

Ethics approval and consent to participate

Not applicable

Consent for publication

Not applicable

Competing interests

The authors declare that they have no competing interests.

Received: 18 October 2019 Accepted: 26 February 2020

Published online: 27 March 2020

References

Bang MH, Kim HH, Lee DY, Han MW, Baek YS, Chung DK, Baek NI. Antiosteoporotic activities of fucosterol from sea mustard (Undaria pinnatifida). Food Sci Biotechnol. 2011;20:343-7.

Devi GK, Manivannan K, Thirumaran G, Rajathi FA, Anantharaman P. In vitro antioxidant activities of selected seaweeds from Southeast coast of India. Asian Pac J Trop Med. 2011;4:205-11.

Guerra Dore CM, Faustino Alves MG, Santos ND, Cruz AK, Câmara RB, Castro AJ, Guimarães Alves L, Nader HB, Leite EL. Antiangiogenic activity and direct antitumor effect from a sulfated polysaccharide isolated from seaweed. Microvasc Res. 2013;88:12-8. 
Ham YM, Kim KN, Lee WJ, Lee NH, Hyun CG. Chemical constituents from Sargassum micracanthum and antioxidant activity. Int J Pharmacol. 2010;6:147-51.

Hosokawa M, Kudo M, Maeda H, Kohno H, Tanaka T, Miyashita K. Fucoxanthin induces apoptosis and enhances the antiproliferative effect of the PPARY ligand, troglitazone, on colon cancer cells. Biochim Biophys Acta. 2004;1675:113-9.

Ikeda I, Tanaka K, Sugano M, Vahouny GV, Gallo LL. Inhibition of cholesterol absorption in rats by plant sterols. J Lipid Res. 1988;29:1573-82.

International conference on harmonization $(\mathrm{ICH})$ of technical requirements for registration of pharmaceuticals for human use, topic Q2A: Text on validation of analytical procedures. US FDA Federal Register. R1. Validation of analytical procedures: text and methodology. 2005;60:11260-6.

International conference on harmonization Q2B: Validation of analytical procedures-methodology. US FDA Federal Register. 1997:62:27463-7.

Jeon YE, Yin XF, Lim SS, Chung CK, Kang IJ. Antioxidant activities and acetylcholinesterase inhibitory activities from seaweed extracts. J Korean Soc Food Sci Nutr. 2012;41:443-9.

Lee DS, Park WS, Heo SJ, Cha SH, Kim D, Jeon YJ, Park SG, Seo SK, Choi JS, Park SJ, Shim EB, Choi IW, Jung WK. Polyopes affinis alleviates airway inflammation in a murine model of allergic asthma. J Biosci. 2011;36:869-77.

Lee YS, Shin KH, Kim BK, Lee S. Anti-diabetic activities of fucosterol from Pelvetia siliquosa. Arch Pharm Res. 2004;27:1120-2.

Majik MS, Adel H, Shirodkar D, Tilvi S, Furtado J. Isolation of stigmast-5, 24-dien-3 ol from marine brown algae Sargassum tenerrimum and its antipredatory activity. RSC Adv. 2015:5:51008-11.

Meenakshi S, Umayaparvathi S, Arumugam M, Balasubramanian T. In vitro antioxidant properties and FTIR analysis of two seaweeds of Gulf of Mannar. Asian Pac J Trop Biomed. 2011;1:S66-70.

Perumal P, Sowmiya R, Prasanna Kumar S, Ravikumar S, Deepak P, Balasubramani G. Isolation, structural elucidation and antiplasmodial activity of fucosterol compound from brown seaweed, Sargassum linearifolium against malarial parasite Plasmodium falciparum. Nat Prod Res. 2018;32:1316-9.

Shanmugam N, Rajkamal P, Cholan S, Kannadasan N, Sathishkumar K, Viruthagiri $\mathrm{G}$, Sundaramanickam A. Biosynthesis of silver nanoparticles from the marine seaweed Sargassum wightii and their antibacterial activity against some human pathogens. Appl Nanosci. 2014;4:881-8.

Souza BWS, Cerqueira MA, Bourbon Al, Pinheiro AC, Martins JT, Teixeira JA, Coimbra MA, Vicente AA. Chemical characterization and antioxidant activity of sulfated polysaccharide from the red seaweed Gracilaria birdiae. Food Hydrocolloid. 2012;27:287-92.

Synytsya A, Kim WJ, Kim SM, Pohl R, Synytsya A, Kvasnička F, Čopíková J, Park YI. Structure and antitumour activity of fucoidan isolated from sporophyll of Korean brown seaweed Undaria pinnatifida. Carbohydr Polym. 2010;81:41-8.

Tang HF, Yang-Hua Y, Yao XS, Xu QZ, Zhang SY, Lin HW. Bioactive steroids from the brown alga Sargassum carpophyllum. J Asian Nat Prod Res. 2002;4:95-101.

Terasaki M, Hirose A, Narayan B, Baba Y, Kawagoe C, Yasul H, Saga N, Hosokawa M, Miyashita K. Evaluation of recoverable functional lipid components of several brown seaweeds (Phaeophyta) from Japan with special reference to fucoxanthin and fucosterol contents. J Phycol. 2009;45:974-80.

Thuy TT, Ly BM, Van TT, Quang NV, Tu HC, Zheng Y, Seguin-Devaux C, Mi B, Ai U. Anti-HIV activity of fucoidans from three brown seaweed species. Carbohydr Polym. 2015;115:122-8.

Veiga-Santos P, Pelizzaro-Rocha K, Santos AO, Ueda-Nakamura T, Dias Filho BP, Silva SO, Sudatti DB, Bianco EM, Pereira RC, Nakamura CV. In vitro antitrypanosomal activity of elatol isolated from red seaweed Laurencia dendroidea. Parasitology. 2010;137:1661-70.

Zhen XH, Quan YC, Jiang HY, Wen ZS, Qu YL, Guan LP. Fucosterol, a sterol extracted from Sargassum fusiforme, shows antidepressant and anticonvulsant effects. Eur J Pharmacol. 2015;768:131-8.

\section{Publisher's Note}

Springer Nature remains neutral with regard to jurisdictional claims in published maps and institutional affiliations.

Ready to submit your research? Choose BMC and benefit from:

- fast, convenient online submission

- thorough peer review by experienced researchers in your field

- rapid publication on acceptance

- support for research data, including large and complex data types

- gold Open Access which fosters wider collaboration and increased citations

- maximum visibility for your research: over $100 \mathrm{M}$ website views per year

At BMC, research is always in progress.

Learn more biomedcentral.com/submissions 